\title{
The structure of the Social Self-Concept (SSC) Questionnaire
}

\author{
Arantza Fernández-Zabala*, Arantzazu Rodríguez-Fernández y Alfredo Goñi
}

Universidad del País V asco / Euskal Herriko Unibertsitatea (UPV/EHU) (Spain).

\begin{abstract}
Título: La estructura del Cuestionario de Autoconcepto Social (AUSO). Resumen: Este estudio tiene por objeto analizar la estructura factorial del Cuestionario de Autoconcepto Social (AUSO), de nueva creación, compuesto por las escalas de responsabilidad social y de competencia social. De la revisión tanto de las teorías del desarrollo social humano como de anteriores intentos de medida del autoconcepto social nació la propuesta teórica de que el autoconcepto social resulta de la conjunción de dos autopercepciones básicas: la competencia en las relaciones sociales y la respuesta a las exigencias del funcionamiento social. Participaron en la investigación 818 estudiantes con edades comprendidas entre 17 y 52 años. Los resultados obtenidos, mediante análisis factoriales confirmatorios, refrendan la estructura hipotetizada de dos factores correlacionados. Este trabajo, además de aportar un nuevo instrumento de medida con características psicométricas adecuadas y criterios válidos que justifican su uso tanto en la práctica aplicada como en el ámbito de la investigación, ayuda a comprender mejor la naturaleza interna del dominio social del autoconcepto.

Palabras clave: Autoconcepto social; desarrollo social; instrumento de medida; fiabilidad; estructura factorial.
\end{abstract}

\section{Introduction}

Self-concept is central to psychological explanations of both personal wellbeing and psychosocial adjustment (Fuentes, García, Gracia, \& Lila, 2011; Rodríguez, Droguett, \& Revuelta, 2012). Consequently, for decades now it has been one of the most-studied elements in this particular field of research. At the beginning of scientific psychology, selfconcept was predominantly viewed as a unidimensional concept, a kind of global perception of the self. From the nineteen-seventies onwards, however, it became generally accepted that the structure of self-concept is organized in a hierarchical, multidimensional manner. According to the bestknown model (Shavelson, Hubner, \& Stanton, 1976), selfconcept is made up of a series of academic and nonacademic perceptions, which in turn form three domains: the social, the emotional or personal and the physical domains.

For decades, attention remained mainly focused on academic self-concept, or precisely, global self-concept in relation to academic achievement. From the nineteen-nineties onwards, however, a new, extremely fertile, area of research opened up focusing on the dimensions or components of each of these three domains, in accordance with the supposition that, rather than improving global self-concept itself, attention should be directed at trying to improve selfperceptions in its specific dimensions or aspects. This new research area gave rise to numerous studies on physical selfconcept (Esnaola, Infante, \& Zulaika, 2011; Esnaola, Rodríguez, \& Goñi, 2011; Goñi, 2008), as well as on the

* Dirección para correspondencia [Correspondence address]:

Arantza Fernández-Zabala. Departamento de Psicología Evolutiva y de la Educación. Universidad del País Vasco / Euskal Herriko Unibertsitatea (UPV/EHU). C/ Juan Ibáñez de Santo Domingo, 1. CP 01006. VitoriaGasteiz (Spain). E-mail: arantza.fernandez@,ehu.es
Abstract: This study aims to analyze the factorial structure of the newlycreated Cuestionario de Autoconcepto Social - AUSO (from here on the Social Self-concept Questionnaire, or AUSO), which consists of two scales measuring social responsibility and social competence. The theoretical proposal which posits that social self-concept is the result of the combination of two basic self-perceptions: competence in social relations and response to the demands of social functioning, is based on a review of human social development theories and previous attempts to measure social self-concept. Participants were 818 students aged between 17 and 52. The results obtained though confirmatory factor analyses support the hypothesis of a structure made up of two correlated factors. In addition to providing a new measurement instrument with appropriate psychometric characteristics and valid criteria that justify its use in both applied practice and research, this study also enhances our understanding of the internal nature of the social domain of self-concept.

Key words: Social self-concept; social development; measuring instrument, reliability, factorial structure.

specific areas of academic self-concept, such as musical selfconcept and artistic self-concept (Vispoel, 1995). More recently, a model of personal self-concept was tested in our environment (Goñi, Madariaga, Axpe, \& Goñi, 2011), distinguishing between self-perceptions of self-fulfillment, autonomy, emotional adjustment and honesty.

During the study of social self-concept, two contrasting approaches emerged which aimed to explain people's perceptions of themselves as social beings either in accordance with different relational contexts (Byrne \& Shavelson, 1996; Musitu, García, \& Gutiérrez, 1991; Shavelson et al., 1976; Song and Hattie, 1984) or depending on their assessment of certain competences (such as, for example, social skills, prosocial behavior, aggressiveness and assertiveness, etc.) that are activated during an individual's social life (Infante et al., 2002; Zorich \& Reynolds, 1988).

In relation to the latter approach, two variants emerged which associated social self-concept with either social acceptance or social competence. Thus, social self-concept is sometimes understood as a person's perception of their social acceptance by their peers, as well as their leadership status and popularity (García, 2001; Harter, 1982, 1985; Harter \& Pike, 1984; Marsh, Barnes, Cairns, \& Tidman, 1984; Neeman \& Harter, 1986; Piers \& Harris, 1984). At other times, however, it is explained in terms of social competence, or in other words, a person's performance with regard to social relations, social skills and sociability (García \& Musitu 2001; Marsh, Parker, \& Barnes, 1985; Roid \& Fitts, 1988). Some questionnaires (Bracken, 1992; Marsh \& O’Niell, 1984; Muller \& Leonetti, 1974) include both dimensions: social acceptance and social competence.

What has yet to be clarified, however, is whether these two dimensions alone (social acceptance and social competence) are sufficient to explain the self-perceptions of social 
development. Social development refers to socialization processes such as the forging of affective bonds, the acquisition of values, social rules and knowledge and the learning of the customs, roles and behaviors that society transmits to its members and demands compliance with (López, Etxebarria, Fuentes, \& Ortiz, 2001). As outlined in different conceptions of social development (Goñi, 2000; Greenberger, 1984), from this perspective, maintaining satisfactory social relations implicitly implies abiding by certain social norms that are established in a conventional way to enable peaceful coexistence between individuals living in the same society. The reason for including a new dimension called social responsibility in social self-concept is linked to the fact that feeling accepted by others and feeling oneself to be socially competent do not globally reflect one's perception of one's social development. This approach is reflected in the unidimensional Social Self-concept Scale developed by Silva and Martinez (2007). The problem here, however, is that the scale, which was administered to the Chilean population, provides no data providing evidence of external validity.

These attempts to thoroughly demarcate the internal structure of social self-concept have been accompanied by a number of different measurement instruments. From the nineteen-eighties onwards, a large number of questionnaires were developed to measure self-concept. However, despite taking into account the different dimensions of self-concept, including the social one (Bracken, 1992; García \& Musitu 2001; Harter, 1982, 1985; Harter \& Pike, 1984; Marsh, et. al., 1985; Marsh \& O`Niell, 1984; Musitu, et. al., 1991; Neeman \& Harter, 1986), these instruments did not aim to measure the internal multidimensionality of social self-concept itself. The few questionnaires developed that did aim to do this (Infante, 2005; Lawson, Mashall, \& McGrath, 1979; Ziller, 1973; Zorich \& Reynolds, 1988) failed to offer good psychometric properties and provided no data regarding the use of confirmatory procedures to clarify the proposed structure.

Based on the above, one can conclude that a comprehensive proposal regarding the internal structure of social self-concept should include the following three dimensions: social acceptance (referring to one's perception of being well-received and well-liked by others), social competence (understood as one's perception of one's ability to function in social situations) and social responsibility (which refers to one's perception of one's contribution to the proper function of society).

In accordance with this theoretical proposal, an initial 23-item version of the Social Self-concept Questionnaire (AUSO) was drafted. The exploratory factor analyses (Goñi \& Fernández-Zabala, 2007) did not enable the hypothesized three dimension structure to be confirmed, but rather indicated a two-factor structure consisting of the social responsibility dimension and a second dimension that combined the responses to items referring to both social competence and social acceptance. These results support the idea that one's perception of oneself as a socially competent being and one's per- ception of oneself as a socially accepted being are so closely related that, in reality, they form a single component, which we propose to call social competence, since this is the more widely used term in psychology. Based on this decision and after eliminating those items that functioned least well in the initial version, the questionnaire presented in this paper was developed.

The main aims of this research project were to verify, using exploratory and confirmatory factor analyses, whether or not social self-perceptions measured using the AUSO fit the hypothesized two-factor structure (social competence and social responsibility), and to check the internal consistency of the questionnaire itself. Three different models were therefore analyzed in accordance with the diverse possible groupings of social self-concept. The first was a unidimensional model (M1), according to which all the items measured a single, undifferentiated structure. The second model (M2) was made up of two uncorrelated factors (social responsibility and social competence). And finally, the third model (M3) was identical to the second one, with the only exception being that the two factors were correlated. We expected the corresponding exploratory and confirmatory factor analyses to confirm a structure made up of two interrelated factors (social competence and social responsibility), with an adequate internal consistency.

\section{Method}

\section{Participants}

A total of 845 students from the University of the Basque Country Teacher Training Colleges participated in the study. Participants were selected using a stratified incidental sampling technique, with different levels and groups being chosen randomly in each college. 27 participants $(3.19 \%)$ were eliminated from the initial sample group because they failed to correctly complete the questionnaire. The final sample group therefore consisted of 818 people: 201 men $(24.6 \%)$ and 617 women $(75.4 \%)$, aged between 17.98 and $52.08(M=20.61 ; S D=3.64)$.

\section{Instruments}

Social self-concept was measured using a modified version of the Social Self-concept Questionnaire (AUSO) by Fernández-Zabala (2011). The questionnaire has a total of 8 items and a Likert-type response scale with five options ranging from $1=$ False to $5=$ True. It is divided into two scales. The first one, called social responsibility, comprises 4 items and refers to the individual's perception of how they contribute to the proper functioning of society: contribution to the common good and commitment to improving humanity; the second one, called social competence, again comprises 4 items and measures the individual's perception of the skills they activate in social situations and how they believe other people react to them. 
In addition to these 8 items, two more were added to control the honesty of the responses given and to verify that participants were completing the questionnaire in a responsible manner, rather than just randomly.

\section{Procedure}

The questionnaire was administered by the authors during teaching hours in the classroom, after obtaining the corresponding consent of the management teams at the various teacher training colleges participating in the study. All participants were assured that their answers would be completely anonymous, although they were not told what the purpose of the project was (single blind) in order to encourage them to be totally honest in their responses and to decrease the likelihood of the social desirability bias. Since the questionnaire was administered as part of a battery of different measurement instruments, the time required for completion varied between 20 and 30 minutes.

\section{Data analysis}

Missing data were corrected using the covariance matrix and the multiple imputation technique (MTMM), following the weighted least squares (WLS) method, since the required normality condition was not fully met. The Lisrel 8.8 statistical program for Windows was used for this (Jöreskog \& Sörbom, 2006).

In order to verify the discriminatory power of each of the items that made up the questionnaire, a descriptive analysis of the 8 items was conducted, consisting of the following statistical calculations: arithmetic mean, standard deviation, asymmetry and kurtosis (Carretero-Dios \& Pérez, 2005).

When the aim of an empirical piece of research is to study the factorial structure of a questionnaire based on exploratory and confirmatory analyses, the sample has to be divided into two random halves. An exploratory factor analysis was therefore conducted on one half of the sample group using the iterated principal axis factoring approach with oblimin rotation. In accordance with current methodological recommendations regarding exploratory factor analyses (Schmitt, 2011), we opted for this method because the two scales (social responsibility and social competence) were significantly correlated $(r=.372 ; p<.01)$.

In order to calculate the degree of internal consistency we used Cronbach's alpha coefficient and McDonald's omega coefficient, estimated on the basis of the saturations obtained for each item in the exploratory factor analysis.

For the confirmatory factor analysis, which was conducted on the other half of the sample group, the alternative or added model fit analysis strategy was used, since this is a procedure which enables an empirical approach to different multidimensional theoretical views of the same measure (Bentler \& Dudgeon, 1996; Tomás \& Oliver, 1998). The models were compared in accordance with the maximum likelihood method, taking the covariance matrix as the input for the data analysis. The fit of each model was assessed using the most common combination of absolute and relative goodness-of-fit indexes (Esnaola, Rodríguez, et al., 2011; Hu \& Bentler, 1999): (a) the ratio between the chi-squared value and the degrees of freedom $\left(\chi^{2} / \mathrm{df}\right)$, the optimal value of which is under 3.00 (Marsh \& Hau, 1996); (b) RMSEA (Root Mean Square Error Approximation), whose score should ideally be below .05, although values of between .05 and .08 are considered indicative of acceptable fit; (c) SRMR (Standardized Root Mean Residual), whose value should be below .05; and (d) the NNFI (Non-Normed Fit Index) and CFI (Comparative Fit Index) indicators, whose minimum threshold of acceptance is a score of .95 .

\section{Results}

\section{Descriptive analyses}

Prior to the factor analyses and in order to ensure the replicability of the study, the means and standard deviations for the observed variables (items) were calculated (see table 1), along with the matrix of correlations between said variables (see table 2).

Furthermore, since any analysis of the psychometric properties of the questionnaire items (carried out to determine their discriminatory capacity) requires the combination of four different statistics (mean, standard deviation, asymmetry and kurtosis), table 1 also contains the results obtained for the latter two of these: asymmetry and kurtosis

Table 1. Descriptive statistics of the observed variables.

\begin{tabular}{|c|c|c|c|c|c|}
\hline Item & Factor Statement & $M$ & $S D$ & Asymmetry & kurtosis \\
\hline i1 & SR Me siento implicado/a con la sociedad [I feel involved in society] & 3.81 & .81 & -.38 & .19 \\
\hline i2 & Me siento aceptado/a cuando estoy en un grupo [I feel accepted when I am in a group] & 4.32 & .70 & -.92 & 1.05 \\
\hline i3 & $\begin{array}{l}\text { Tengo mucho éxito en mis relaciones con la gente [I am very successful in my relationships } \\
\text { with people] }\end{array}$ & 3.78 & .73 & -.29 & .35 \\
\hline i4 & Colaboro para mejorar la sociedad [I do my bit to improve society] & 3.53 & .84 & -.25 & .47 \\
\hline i5 & Caigo bien a la gente [People tend to like me] & 3.88 & .67 & -.01 & -.43 \\
\hline i6 & Me siento útil en la sociedad [I feel useful in society] & 3.70 & .77 & -.12 & -.05 \\
\hline i7 & $\begin{array}{l}\text { Cumplo adecuadamente las obligaciones que tengo como ciudadano/a [I fulfill my obliga- } \\
\text { tions as a citizen] }\end{array}$ & 3.81 & .76 & -.29 & .06 \\
\hline i8 & Tengo muchos amigos [I have a lot of friends] & 4.03 & .91 & -.93 & .87 \\
\hline
\end{tabular}


The mean for the responses given to the different items oscillated between 3.53 (i5) and 4.32 (i2), although it was generally slightly higher than the midway point that is deemed desirable for this scale (in this case, 3 ). In relation to standard deviation, the scores obtained were very close to the recommended value of 1 (Nunnally \& Bernstein, 1995), while all the asymmetry and kurtosis indexes were below the established limits (2 and 7, respectively) and are therefore acceptable (West, Finch, \& Curran, 1995).

\begin{tabular}{|c|c|c|c|c|c|c|c|c|}
\hline Item & i1 & i2 & i3 & i4 & i5 & i6 & i7 & i8 \\
\hline i1 & 1 & & & & & & & \\
\hline i2 & $.268^{* *}$ & 1 & & & & & & \\
\hline i3 & $.238^{* *}$ & $.411^{* *}$ & 1 & & & & & \\
\hline i4 & $.521^{* *}$ & $.165^{* *}$ & $.214^{* *}$ & 1 & & & & \\
\hline i5 & $.198 * *$ & $.353^{* *}$ & $.503^{* *}$ & $.189 * *$ & 1 & & & \\
\hline i6 & $.541 * *$ & $.350 * *$ & $.311^{* *}$ & $.491^{* *}$ & $.331 * *$ & 1 & & \\
\hline i7 & $.293 * *$ & $.138^{* *}$ & $.119^{* *}$ & $.320^{* *}$ & $.108^{* *}$ & $.333^{* *}$ & 1 & \\
\hline i8 & $.202^{* *}$ & $.346^{* *}$ & $.441 * *$ & $.185^{* *}$ & $.339 * *$ & $.213^{* *}$ & $.119 * *$ & 1 \\
\hline
\end{tabular}

The correlation matrix shown in table 2 reflects significant correlations in all cases between the items that make up the questionnaire. These correlations oscillated between $r=$ .108 and $r=.541(p<.01)$. No correlation exceeded $r=.90$, thus enabling the possibility of multicollinearity between items to be dismissed.

\section{Exploratory factor analysis and reliability}

One vital requirement for conducting an exploratory factor analysis is that the items be related to each other, thus enabling relevant groupings to be identified. Given that the correlations between some items were low, sampling adequacy was analyzed before the exploratory factor analysis was carried out. The Kasier-Meyer-Olkin index $(\mathrm{KMO}=$ $.806)$ and Bartlett's test of sphericity $\left(\chi^{2}{ }_{(28)}=1568.321 ; p<\right.$ $.000)$ indicated that the correlation matrix was adequate; in other words, they confirmed that the relationship between items was significant and that an exploratory factor analysis was indicated. The configuration matrix resulting from the exploratory factor analysis is presented in Table 3.

Table 3. Exploratory factor analysis.

\begin{tabular}{lcc}
\hline \multirow{2}{*}{ Item } & \multicolumn{2}{c}{ Factor } \\
\cline { 2 - 3 } & $\mathrm{I}$ & $\mathrm{II}$ \\
\hline $\mathrm{i} 1$ &. $\mathbf{7 2 7}$ & .008 \\
$\mathrm{i} 4$ & .715 & -.043 \\
$\mathrm{i} 6$ & .664 & .156 \\
$\mathrm{i} 7$ & .449 & -.024 \\
$\mathrm{i} 3$ & -.057 & $\mathbf{. 7 9 2}$ \\
i5 & -.002 & $\mathbf{. 6 4 0}$ \\
i8 & -.006 & $\mathbf{. 5 6 5}$ \\
i2 & .090 & $\mathbf{. 5 2 7}$ \\
\hline Eigenvalues & 3.101 & 1.405 \\
\% variance explained & 38.765 & 17.565 \\
Cronbach's alpha & .7179 & .7419 \\
McDonald's omega & .825 & .825 \\
Average variance extracted & .545 & .546 \\
\hline I = social responsibility; II = social competence & &
\end{tabular}

$\mathrm{I}=$ social responsibility; II = social competence
The results clearly reflect a consistent two-factor structure that is supported by the theoretical approach and which explains $56.33 \%$ of the common variance. All the items obtained adequate saturation values above the required level of .40 (Stevens, 1992) in their corresponding factor, thus confirming the hypothesized composition according to which the 4 items designed to measure social responsibility would be grouped together and the 4 remaining items, designed to measure social competence, would be grouped in a different factor, thereby confirming the multidimensionality of social self-concept.

The internal consistency of the questionnaire was calculated using Cronbach's alpha index, with an acceptable value of .77 being obtained (Nunnally \& Bernstein, 1995). When reliability based on the saturation levels of the items in the exploratory factor analysis was taken as a reference, the results improved considerably, obtaining a McDonald's omega value of .904 (average variance extracted $=.546$ ).

\section{Confirmatory factor analysis}

Table 4 below shows the results of the confirmatory factor analysis, which was verified for each of the proposed models.

The results indicate that both the unidimensional model (M1) $\left(\chi^{2} / \mathrm{df}=26.38 ;\right.$ RMSEA $=.176 ; \mathrm{NNFI}=.66$; $\mathrm{CFI}=$ .75 ; RSMR $=.095)$ and the two-factor model with uncorrelated factors $(\mathrm{M} 2)\left(\chi^{2} / \mathrm{df}=9.01 ; \mathrm{RMSEA}=.099 ; \mathrm{NNFI}=\right.$ .84 ; CFI $=.89$; RSMR $=.155)$ had a poor fit, since none of the goodness-of-fit indexes calculated for either reached the established minimum level.

The model which obtained the best results was the third one (M3), with two correlated factors $\left(\chi^{2} / \mathrm{df}=3.29\right.$; RMSEA $=.053 ; \mathrm{NNFI}=.96 ; \mathrm{CFI}=.97 ; \mathrm{RSMR}=.034 ; \Delta \chi^{2}$ $\left.\mathrm{M}_{2}-\mathrm{M}_{3}=117.53 ; p<.001\right)$, although it should be highlighted that the score obtained after calculating the ratio between the chi-squared value and the number of degrees of freedom $(\chi 2 / d f)$ did not correspond to that considered indicative of good fit (under 3.00) (Marsh \& Hau, 1996), although it was 
close to this value. Nevertheless, the fit of this model improved considerably $\left(\chi^{2} / \mathrm{df}=3.29\right.$; RMSEA $=.053$; NNFI $=$ $.96 ; \mathrm{CFI}=.97 ; \mathrm{RSMR}=.034 ; \Delta \chi^{2} \mathrm{M}_{3}-\mathrm{M}_{3 \mathrm{~L}}=21.81 ; p<$ .001) following the progressive liberation of the correlations between the measurement errors of the two pairs of items whose modification indexes for the Theta-delta matrix were over 20, due to measurement artifacts external to the instrument (M3L). Specifically, the inter-correlation of the errors between items 1 and 4, and between items 2 and 6, were liberated, as the result of semantic similarities within each item pair.

Table 4. Confirmatory factor analysis.

\begin{tabular}{lcccccccc}
\hline Model & $\chi^{2}$ & $\mathrm{df}$ & $\chi^{2} / \mathrm{df}$ & $\mathrm{p}$ & $\begin{array}{c}\text { RMSEA } \\
(90 \% \text { confidence interval })\end{array}$ & NNFI & CFI & SRMR \\
\hline $\mathrm{M}_{1}$ & 527.58 & 20 & 26.38 & .000 & .176 & $.16)$ & .75 & .095 \\
\hline $\mathrm{M}_{2}$ & 180.12 & 20 & 9.01 & .000 & $\begin{array}{c}.099 \\
.086-.11)\end{array}$ & .84 & .89 & .15 \\
\hline $\mathrm{M}_{3}$ & 62.59 & 19 & 3.29 & .000 & $\begin{array}{c}.053 \\
(.039-.068)\end{array}$ & .96 & .97 & .034 \\
\hline $\mathrm{M}_{3 \mathrm{~L}}$ & 40.78 & 17 & 2.40 & .001 & .041 & $.025-.058)$ & .99 & .026 \\
\hline Min. established & & & $<3$ & $<.05$ & $<.05 /<.08$ & $>.95$ & $>.95$ & $<.05$
\end{tabular}

M1 = unidimensional model; M2 = two-factor model of uncorrelated factors; M3 = two-factor model of correlated factors; M3L = two-factor model of correlated factors corrected through the liberation of two errors

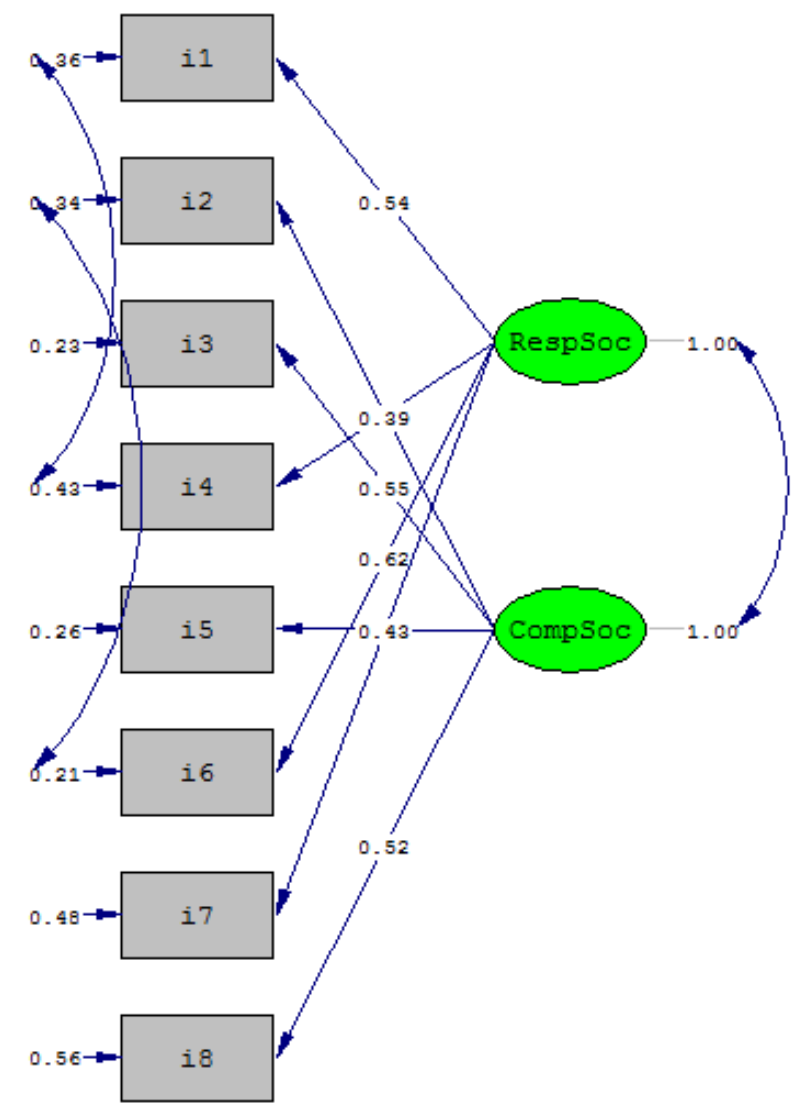

Figure 1. Two-factor model of social self-concept.

Figure 1 contains a graphic representation of the twofactor model of correlated factors, corrected through the liberation of these two errors (M3L), since this was found to be the best model for explaining the factorial structure of the AUSO.

\section{Discussion}

Although interest in social self-concept is by no means a recent development, there is a distinct lack of studies attempting to demarcate its internal structure, or in other words, to elucidate the number and nature of the principal dimensions that account for said structure in a satisfactory manner. This study presents empirical data that support a theoretical model of social self-concept, along with a measurement instrument, the Social Self-concept Questionnaire (AUSO), that was developed in accordance with said model. It is a fast screening method for adolescents and young adults that offers good psychometric characteristics that justify its use and application in both applied practice and research. Thus, the instrument is a useful tool that enables a more precise identification of those students who experience difficulties in their social relations, in order to permit the design of appropriate prevention programs.

The results confirm the validity of the initial hypothesis, dismissing the unidimensional model (which cannot be overlooked) in which social self-concept is understood as a single factor, and finding psychometric support for the two-factor model with correlated factors, based on two liberations of covariance between items. Two basic components repeatedly appear in previous studies on the nature of social selfconcept: social competence and social acceptance (Bracken, 1992). These components tend to overlap, since one's perception of oneself as a being accepted by others is simply another way of assessing one's competence at a social level. Nevertheless, the results found here provide empirical evidence supporting the two-factor proposal (social responsibility and social competence) with interrelated factors, which 
encompasses those aspects of social development which are necessary to obtaining a more comprehensive view of social self-perceptions. It is not enough just to perceive oneself as socially competent; in order to ensure adequate adaptation to the social milieu in which one is immersed since birth, one must also understand and respect the structure of society.

Differentiating between specific components within generic constructs is proving to be a timely, necessary exercise in psychosocial fields such as social support (Wongpakaran \& Wongpakaran, 2012), burnout syndrome (ManzanoGarcía \& Ayala-Calvo, 2013; Rodríguez \& Fernández, 2012), wellbeing (Rodríguez \& Goñi, 2011) and self-concept (Tomás \& Oliver, 2004). Having a precise idea of the different components that make up these constructs opens up new avenues of research for psychological understanding and intervention. This coincides with the theoretical assumptions of Marsh and Shavelson's model (1985), according to which global self-concept is made up of various domains (academic, personal, social and physical), each of which is divided into a series of sub-domains, facets or more specific dimensions. One of the principal postulates of this model is that, although global self-concept itself is resistant to change, its specific dimensions can be modified, and therefore require specific psychological intervention.

Indeed, it is precisely intervention expectations in both the field of physical education and the clinical context which have, from the nineteen-nineties onwards, driven research into physical self-concept. Direct relationships have been identified in this last construct, along with a large number of social-personal traits, such as physical activity, body mass index, healthy living habits, psychological wellbeing and anxiety (Infante \& Goñi, 2009). Identifying these types of connections is extremely valuable, since it reveals new perspectives

\section{References}

Bentler, P. M., \& Dudgeon, P. (1996). Covariance structure analysis: Statistical practice, theory, and directions. Annual Review of Psychology, 47, 563592. doi: 10.1146/annurev.psych.47.1.563

Bracken, B. (1992). The multidimensional Self Concept Scale. Austin, TX: Pro-Ed.

Byrne, B. M., \& Shavelson, R. J. (1996). On the structure of social selfconcept for pre-, early and late adolescents: A test of the Shavelson et al. model. Journal of Personality and Social Psychology, 70, 599-613. doi: $10.1037 / / 0022-3514.70 .3 .599$

Carretero-Dios, H., \& Pérez, C. (2005). Normas para el desarrollo y revisión de estudios instrumentales [Standards for the development and review of instrumental studies]. International Journal of Clinical and Health Psychology, 5, 521-551.

Esnaola, I., Infante, G., \& Zulaika, L. M. (2011). The multidimensional structure of physical self-concept. The Spanish Journal of Psychology, 14(1), 304-312. doi: 10.5209/rev_SJOP.2011.v14.n1.27

Esnaola, I., Rodríguez, A., \& Goñi, E. (2011). Propiedades psicométricas del cuestionario de Autoconcepto AF5 [Psychometric properties of the questionnaire AF5]. Anales de Psicología, 27(1), 109-117.

Fernández-Zabala, A. (2011). El autoconcepto social en la adolescencia y juventud: Dimensiones, medida y relaciones [The social self-concept in adolescence and youth: Dimensions, measurement and relationships]. Dissertation. Leioa, Spain: $\mathrm{UPV} / \mathrm{EHU}$. from which to approach educational interventions designed to help individuals achieve better personal adjustment.

A similar contribution may be expected from a more precise knowledge of the structure and dimensions of social self-concept, a variable which is clearly related to elements such as psychological wellbeing, which are vital to our health (Fernández-Zabala, 2011). Having a measurement instrument with adequate psychometric characteristics, such as the AUSO, will enable a more precise understanding of the function of self-concept, and each of its components, in human behavior.

In short, this study fulfils the aim of providing an adequate psychometric measurement instrument of two different dimensions of social self-concept, which supports the widely-accepted multidimensional view of self-concept. However, it also raises a number of unanswered questions.

The results fail to completely answer all the questions raised regarding the multidimensional and hierarchical composition and structure of self-concept. It would, for example, be interesting to analyze the relationship between social responsibility, understood as a dimension of social selfconcept, and the moral dimension of personal self-concept, since these are two separate dimensions both related to social life. This opens up a number of new avenues for research, just as this view of social self-concept raises the need to study the relationships which exist between each of the dimensions and other psychological variables, such as social skills, social support and even social status.

Acknowledgments.- This study was conducted within the framework of the EDU2009-10102 project, subsidized by the MICINN (Spain), with the help of grants aimed at supporting the activities of research groups within the Basque university system (Basque Official Gazette 27-VII-2012 Application IT701-13).

Fuentes, M. C., García, J. F, Gracia, E., \& Lila, M. (2011). Autoconcepto y ajuste psicosocial en la adolescencia [The self-concept and psychosocial adjustment in adolescence]. Psicothema, 23(1), 7-12.

García, B. (2001). CAG: Cuestionario de Autoconcepto: Manual [CAG: Self-concept Questionnaire: Manual. Madrid, Spain: EOS.

García, F., \& Musitu, G. (2001). AF5: Autoconcepto Forma 5 [AF5: Self-concept Form 5]. Madrid, Spain: TEA.

Goñi, A. (2000). Psicologia del individualismo [Psychology of individualism]. San Sebastián-Donostia, Spain: Erein.

Goñi, A. (Ed.) (2008). El autoconcepto fisico. Psicología y educación [The physical selfconcept. Psychology and education]. Madrid, Spain: Pirámide.

Goñi, E., Madariaga, J. M, Axpe, I., \& Goñi, A. (2011). Structure of the Personal Self-Concept (PSC) questionnaire. International Journal of Clinical and Health Psychology, 11(3), 509-522.

Goñi, E., \& Fernández-Zabala, A. (2007). Los dominios social y personal del autoconcepto [The social and personal domains of self-concept]. Revista de Psicodidáctica, 12(2), 179-194

Greenberger, E. (1984). Defining psychosocial maturity in adolescence. Advances in Child Behavioral Analysis and Therapy, 3, 1-37.

Harter, S. (1982). The Perceived Competence Scale for Children. Child Development, 53(1), 87-97. doi: 10.2307/1129640

Harter, S. (1985). Manual for the Self-Perception Profile for Children. (Revision of the Perceived Competence Scale for Children). Denver, C.O.: University. 
Harter, S., \& Pike, R. (1984). The Pictorial Scale of Perceived Competence and Social Acceptance for young children. Child Development, 55, 19691982. http://dx.doi.org/10.2307/1129772

Hu, L., \& Bentler, P. M. (1999). Cut-off criteria for fit indices in covariance structure analysis: Conventional criteria versus new alternatives. Structural Equation Modeling, 6, 1-55. doi: 10.1080/10705519909540118

Infante, G., \& Goñi, E. (2009). Actividad físico-deportiva y autoconcepto físico en la edad adulta [Physical activity and physical self-concept in middle-age adults]. Revista de Psicodidáctica, 14, 49-62.

Infante, L. (2005). Cuestionario de autoconcepto social: Justificación y propiedades psicométricas [Social self-concept questionnaire: Psychometric properties and justification] (Unpublished dissertation). University of Malaga, Spain.

Infante, L., De la Morena, L., García, B., Sánchez, A., Hierrezuelo, L., \& Muñoz, A. (2002). Un estudio sobre el autoconcepto social en estudiantes de E.S.O.: Diferencias de género [A research of the social selfconcept with high school students: Gender differences]. Revista Electrónica Interuniversitaria de Formación del Profesorado, 5(3), 1-7. Retrieved from: http://www.revistaeducacion.educacion.es/re352/re352 22.pdf

Jöreskog, K. G., \& Sörbom, D. (2006). LISREL 8.8 for windows Computer software]. Lincolnwood, IL: Scientific Software International.

Lawson, J. S., Marshall, W. L., \& McGrath, (1979). The social self-esteem inventory. Educational and Psychological Measurement, 39, 803-811. doi: 10.1177/001316447903900413

López, F., Etxebarria, I., Fuentes, M. J., \& Ortiz, M. J. (2001). Desarrollo afectivo y social [Emotional and social development]. Madrid, Spain: Pirámide.

Manzano-García, G., \& Ayala-Calvo, J. C. (2013). New Perspectives: Towards an Integration of the concept "burnout" and its explanatory models. Anales de Psicología, 29(3), 800-809. Doi: 10.6018/analesps.29.3.145241

Marsh, H. W., Barnes, J., Cairns, L., \& Tidman, M. (1984). Self-Description Questionnaire: Age and sex effects in the structure and level of selfconcept for preadolescent children. Journal of Educational Psychology, 76(5), 940-956. doi: 10.1037//0022-0663.76.5.940

Marsh, H. W., Parker, J., \& Barnes, J. (1985). Multidimensional adolescent self-concepts: Their relationships to age, sex and academic measures. American Educational Research Journal, 22, 422-444. doi: 10.3102/00028312022003422

Marsh, H. W., \& Hau, K. (1996). Assessing goodness of fit: Is parsimony always desirable? Journal of Experimental Education, 64, 364-390. Doi: 10.1080/00220973.1996.10806604

Marsh, H. W., \& O`Neil, R. (1984). Self Description Questionaire III (SDQIII): The construct validity for multidimensional self concept ratings by late adolescents. Journal of Educational Measurement, 21, 153-174. doi: 10.1111/j.1745-3984.1984.tb00227.x

Marsh, H., \& Shavelson, R. (1985). Self-concept: Its multifaceted, hierarchical structure. Educational Psychologist, 20, 107-123. doi : $10.1207 /$ s15326985ep2003_1

Muller, D. G., \& Leonetti, R. (1974). Primary Self-concept Inventory Test Manual. Austin, TX: Learning Concepts.

Musitu, G., García, F., \& Gutiérrez, M. (1991). Autoconcepto Forma A. Manual [Self-concept Form A. Manua]. Madrid, Spain: TEA.

Neeman, J., \& Harter, S. (1986). The Self-Perception Profile for College Students. Denver: University.

Nunnally, J., \& Bernstein, I. (1995). Teoría psicométrica [Psychometric theory]. México: McGraw-Hill.
Piers, E. V., \& Harris, D. B. (1984). Manual for the Piers-Harris Children's Self Concept Scale. Los. Angeles, CA: Western Psychological Services.

Rodríguez, A., Droguett, L., \& Revuelta, L. (2012). School and personal adjustment in adolescence: The role of academic self-concept and perceived social support. Revista de Psicodidáctica, 17(2), 397-414. doi: 10.1387/RevPsicodidact.3002

Rodríguez, A., \& Goñi, A. (2011). La estructura tridimensional del bienestar subjetivo [The three-dimensional structure of the subjective well-being]. Anales de psicología, 27(2), 327-332.

Rodríguez, J. M., \& Fernández, M. J. (2012). Development and validation of a measuring instrument for Burnout Syndrome in teachers. The Spanish Journal of Psychology, 15(3), 1456-1465. doi: 10.5209/rev_SJOP.2012.v15.n3.39429

Roid, G., \& Fitts, W. (1988). Tennessee Self-Concept Scale, Revised Manual. Los Angeles, CA: Western Psychological Services.

Schmitt, T. A. (2011). Current methodological considerations in exploratory and confirmatory factor analysis. Journal of Psichoeducational Assessment, 29, 304-321. doi: 10.1177/0734282911406653

Shavelson, R., Hubner, J., \& Stanton, J. (1976). Self-concept: Validation of construct interpretations. Review of Educational Research, 46(3), 407-441. doi: 10.3102/00346543046003407

Silva, C., \& Martínez, L. (2007). Empoderamiento, participación y autoconcepto de persona socialmente comprometida en adolescentes chilenos [Empowerment, participation and social self-Concept in chilean adolescents]. Revista Interamericana de Psicología, 41(2), 129-138.

Song, I., \& Hattie, J. (1984). Home environment self-concept and academic achievement: A causal modeling approach. Journal of Educational Psycholo$g y, 76,1269-1281$. doi: 10.1037//0022-0663.76.6.1269

Stevens, J. (1992). Applied multivariate statistics for the social sciences. Hillsdale, NJ: Lawrence Erlbaum.

Tomás, J. M., \& Oliver, A. (1998). Efectos de formato de respuesta y método en análisis factorial confirmatorio [Response format and method of estimation effects on confirmatory factor analysis]. Psicothema, 10(1), 197-208.

Tomás, J. M., \& Oliver. A. (2004). Análisis psicométrico confirmatorio de una medida multidimensional del autoconcepto en español [Confirmatory Factor Analysis of a Spanish Multidimensional Scale of SelfConcept]. Revista Interamericana de Psicología, 38(2), 285-293.

Vispoel, W. (1995). Self-concept in artistic domains: An extension of the Shavelson, Hubner, and Stanton (1976) model. Journal of Educational Psychology, 87(1), 134-153. doi: 10.1037//0022-0663.87.1.134

West, S. G., Finch, J. F., \& Curran, P. J. (1995). Structural equation models with non-normal variables: Problems and remedies. En R. H. Hoyle (Ed.), Structural equation modeling: Concepts, issues and applications (pp. 5675). Thousand Oaks, CA: Sage Publications.

Wongpakaran, N., \& Wongpakaran, T. (2012). A revised thai multidimensional scale of perceived social support. The Spanish Journal of Pychology, 15(3), 1503-1509. doi: 10.5209/rev_SJOP.2012.v15.n3.39434

Ziller, R. C. (1973). The social self. New York, NY: Pergamon.

Zorich, S., \& Reynolds, W. M. (1988). Convergent and discriminant validation of a measure of social self-concept. Journal of Personality Assessment, 52(3), 441-453. doi: 10.1207/s15327752jpa5203_5

(Article received: 05-03-2014; revised: 07-01-2015; accepted: 26-02-2015) 